\title{
Impact of Nitrate Vulnerable Zones and Catchment Sensitive Farming on Water Quality in UK: Case Study of Ingbirchworth and Scout Dyke Reservoirs
}

ISSN: 2576-8840

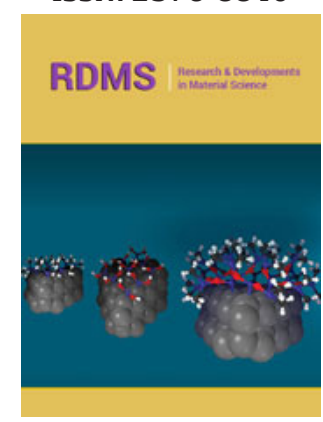

*Corresponding author: Ash Ahmed, Associate Professor of Civil Engineering Group, UK

Submission: 紫 December 23, 2020

Published: 漹January 15, 2021

Volume 14 - Issue 5

How to cite this article: Hafiz Muhammad Nadir, Ash Ahmed. Impact of Nitrate Vulnerable Zones and Catchment Sensitive Farming on Water Quality in UK: Case Study of Ingbirchworth and Scout Dyke Reservoirs. Res Dev Material Sci. 14(5). RDMS.000848. 2021. DOI: 10.31031/RDMS.2021.14.000848

Copyright@ Ash Ahmed and Hafiz Muhammad Nadir. This article is distributed under the terms of the Creative Commons Attribution 4.0 International License, which permits unrestricted use and redistribution provided that the original author and source are credited.

\author{
Hafiz Muhammad Nadir ${ }^{1}$ and Ash Ahmed ${ }^{2 *}$ \\ ${ }^{1}$ Doctoral Researcher, Civil Engineering Group, Leeds Beckett University, UK
}

2Associate Professor of Civil Engineering Group, Leeds Beckett University, UK

\begin{abstract}
The rivers and water streams are considered as a source of fresh drinking water for the human being on earth. The main source of water entering to these reservoirs is surface run off, snow melting and underground water. The water at the river's mouth is generally in the form of small streams which are considered clean but as they flow down the catchment, pollutants and nutrients start to enter in larger amounts due to anthropogenic activities and advanced land use by human beings. As per inspection of chief inspector "Drinking Water Inspectorate (DWI)" in 2016, out of more than 4600 water bodies and 3700 rivers in England, only one sixth could get "good" status and two third could get "moderate" status as per European union standards. This is though a good achievement in Europe but alarming also, as all rivers are required to have achieved specified "good" standards by 2021 (extended to 2027 for some categories). This phenomenon is pronouncing more complications in drinking water reservoirs or compensatory reservoirs from where water is taken out to utility companies and treated for domestic water supply incurring an enormous cost on its treatment before human consumption. The clean water standards can be achieved only if a strict control is implemented on entry of pollutants/ nutrients from surface run off using thorough catchment scale sensitive strategies. UK has been implementing strict measures under Environment Agency (EA), Department for Environment, Food and Rural Affairs (DEFRA) and other organizations like "Natural England", "River Trust" and water utility/ supply companies to achieve desired standards of water quality in rivers by managing the whole catchment as per European union water framework directive (EU WFD) 2000.The catchment sensitive farming and nitrate vulnerable zones policies were started in 1992 and has been in full practice by implementing different stewardship schemes and fertilizers control measures in farmlands and arable lands. Ingbirchworth reservoir and Scout Dyke compensatory reservoir have been under catchment sensitive stewardship schemes to control quantities of nutrients especially nitrates and other pollutants since 2006 to maintain good quality water reservoirs for drinking and compensation to Don river. A partial success has been achieved in controlling the values of nitrates, phosphates, and suspended solids to enter from catchment farmlands by controlling the use of slurry/ fertilizers and implementation of good farming techniques. However, temporal and special variations show a variable result of presence of nitrates, phosphates and suspended solids at different streams in different times, more than specified limits of $11.3 \mathrm{mg} / \mathrm{L}, 0.1 \mathrm{mg} / \mathrm{L}$ and $25 \mathrm{mg} / \mathrm{L}$ respectively. This requires more holistic efforts to control the bad practices in farming in adjacent farm/arable lands and improvements in stewardship schemes for catchment sensitive farming in Ingbirchworth areas.
\end{abstract}

Keywords: Catchment sensitive farming;Nitrate vulnerable zones;Water quality;Stewardship farming schemes; Impact; Success

\section{Introduction}

Water is a common resource for all living creatures and is required to be preserved for use by all, in its pure/ natural form [1]. Unfortunately, the natural clean state of water in the rivers/ streams could not be preserved pollution free, mainly due to anthropogenic activities of humankind, land use changes, industrial revolution, heavy modified water bodies, geomorphological changes and climatic variations. All these have impacted the water quality with adverse effects on biodiversity and ecology. The increase in population and technology/ industry advancement have resulted into more use of fresh water from the environment. European Union Water Framework Directive (2000 \& amended in 2012) wants every member state to implement best possible measures to prevent polluting the water streams physically or chemically by managing the complete river catchment as a wholistic approach [2]. This seems to be a gigantic task with less success possibilities but if implemented successfully, can stop doing the modifications and pollutants entry to water bodies throughout the catchment length by all stakeholder/ public partnership. UK has more than 8000 water streams in around 
100 catchments to manage as per River Basin Management Plans prepared/ revised every 6 years by Environment Agency. These are managed to get 'Good Status' as per EU standards by 2021\& 2027 (extended) due to non-attainment of goals set for 2015 [3]. The target to limit Nutrients and sediments into the rivers from farmlands remains a grey area in almost all EU countries and UK $[4,5]$. We are required to implement the best management practices to control all these pollutants entering to streams throughout the length of the river catchments which comprise the implementation of catchment sensitive farming being major source of pollutants, rehabilitation of barren land by forestation, control on land use changes, sediment transport to rivers from tillage/ cropless fields, control on farming and animal waste, preventing free entry of oil/ chemicals from roads as surface run off, control on industrial wastes/ sewerage treatment disposals and preservation of natural course of flow of streams with no/ less modifications.

The anthropogenic pollution of water bodies by mixing of physical, chemical, biological and industrial waste in these streams is a result of increased population and human interventions especially after industrial revolution [6]. Kallis [7], Kaika [8], Adshead [9] \& Grimeaud [10] have explained WFD issuance in 2000 as a historic milestone which combined all previous directives for maintenance of clean and healthy water for drinking/ irrigation/ bathing by preventing mixing/ disposal of waste, chemicals, organic materials, excessive use of nutrients/ manures, industrial waste and heavy modifications to water bodies for benefit of all living organism in all habitats including human beings, plants, birds, animals, microorganism and aqua life [7-10]. The WFD has been evolving over time into a detailed document by integration of various water related directives and policies issued time to time as shown in Figure 1; [11] and ask member states to maintain water reservoir for all purposes free from dangerous pollutants and treatment of wastewater before entering it to water streams through proper treatment plants. The treatment of polluted water is a costly affair and incurring major cost/ difficulty to water agencies in UK to achieve desired standards as implemented by EU WFD especially due to nitrate vulnerable farming in the catchment areas [12].

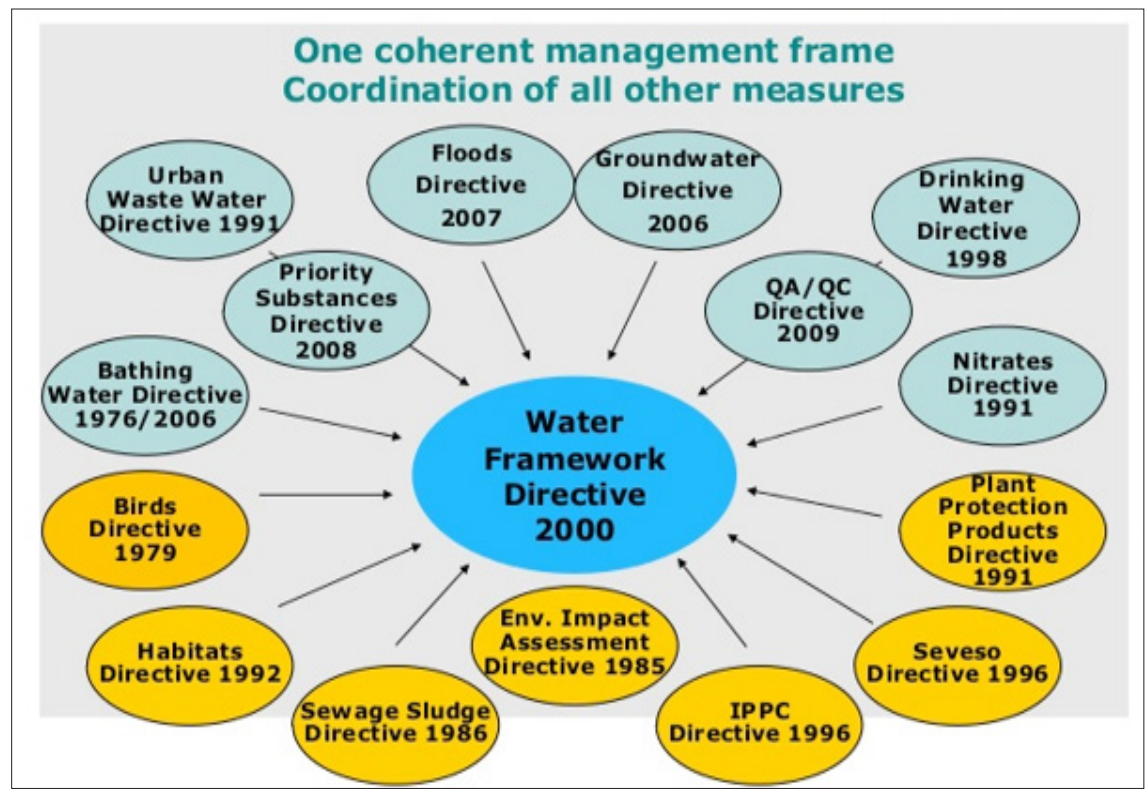

Figure 1: Integration of WFD [11].

The farmlands, cultivated areas and grassy fields are considered as a biggest source of entry of nutrients like Nitrate, Sulphate and Phosphates and Suspended Solids (SS) into water streams and reservoirs due to extensive use of organic manures and chemical fertilizers by farmers. The best solution to overcome the presence of nutrients and Suspended Solids (SS) is to implement a sustainable and sensible land use strategy for controlled agriculture/ farming in the catchment. The agriculture contributes $£ 8$ Billion in UK GDP by employing more than $0.3 \mathrm{M}$ people to do arable farming on three quarters of UK land [13]. However, controlling the farming industry to desired results is very difficult as any restrictions on use of fertilizers/ manures and implementation of catchment sensitive farming measures result into direct reduction of production yield and economic loss to farmers. However, UK government has implemented the rules for catchment sensitive farming with several subsidies to ease out the economic burden on farmers and they were required to implement the rules by 2019 with restricted use of land falling in the catchment vicinity of water reservoirs. The success of catchment sensitive policy is still questionable as much is required to be done by farmers in collaboration with DEFRA (Department for food, environment and rural affairs) and EA (Environment agency UK). This study has been carried out to assess the post implementation scenario/ water quality after incorporation of catchment sensitive farming in Ingbirchworth and Scout areas in 
South Yorkshire. In this study, water samples were collected from Ingbirchworth drinking water supply reservoir and Scout Dyke compensatory reservoirs maintained by Yorkshire Water Agency in the catchment of River Don. These reservoirs are fed by different water streams mainly draining water from surrounding arable/ farmlands of around $11.2 \mathrm{~km}^{2}$ comprising mainly on grassland and some of the cultivated crop lands. This area is being managed by catchment sensitive farming under policies of DEFRA, Nitrate Vulnerable Zones legislation and Catchment Sensitive Farming advice since 2002. Pictorial coverage/ maps of reservoir are given in Figure 2.

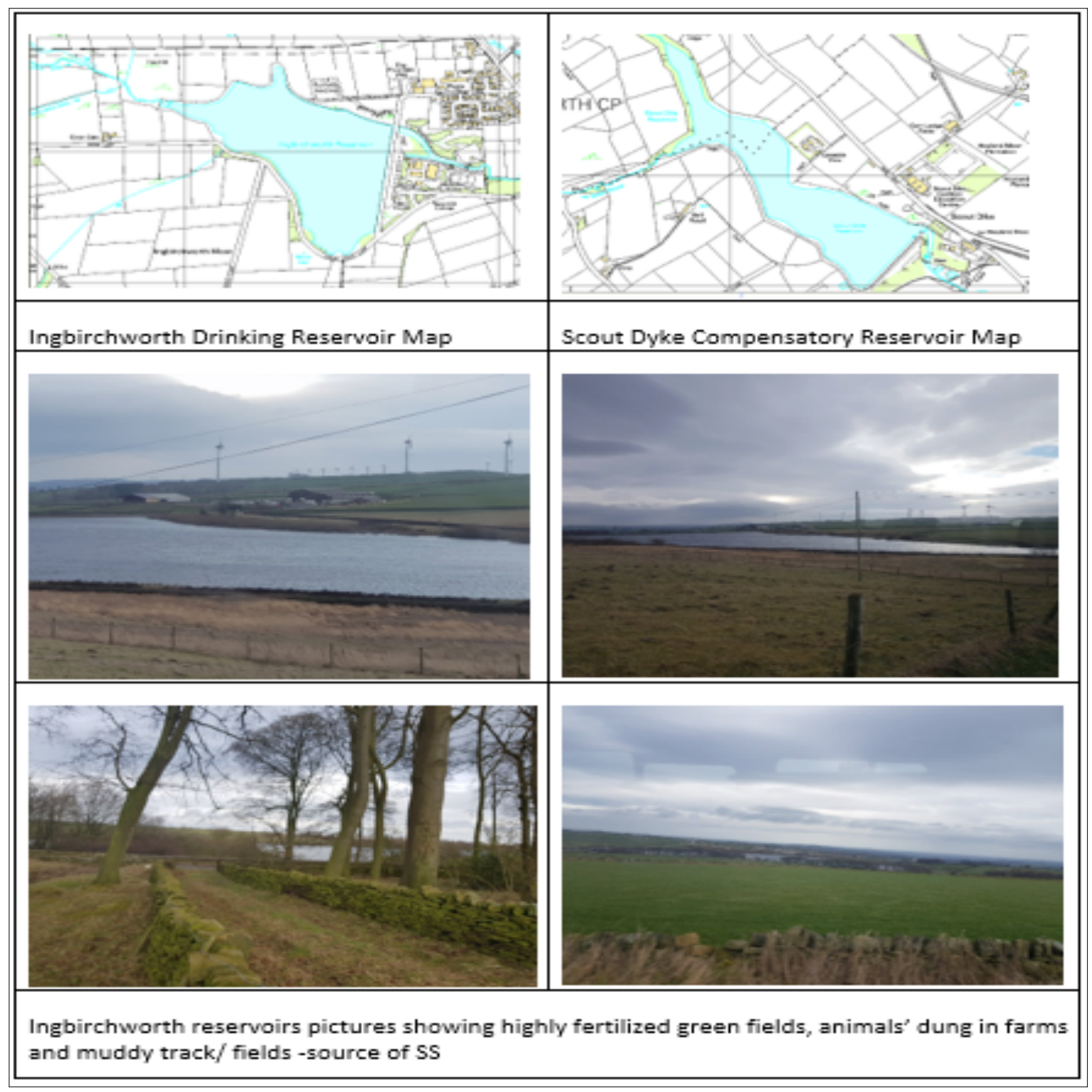

Figure 2: Maps and Pictures Ingbirchworth reservoirs taken during site visit.

\section{Literature Review}

The ever-increasing human interference in nature and especially for last 5 decades after industrial revolution, have caused more intake of nutrients and SS into water streams than ever before $[14,15]$. Edwards and Withers (2008) have studied that the water reservoirs are facing anthropogenic concentration of nutrients and SS due to increased use of fertilisers, manure, slurry, polluted surface drainage, wastewater, modified land use for agriculture, farms, urbanization, deforestation and industry [16]. Up to 70 $\%$ of Nitrogen and 30 to $50 \%$ of phosphorous are coming from agricultural/ farms land into the reservoirs/ water streams in UK [17]. Runoff from arable/ farmlands is producing influx of up to $75 \%$ of SS [18], $25 \%$ of phosphorus and $60 \%$ of nitrate inputs to rivers [19]. Ockenden et al (2012) in their study found that it is difficult to control the influx of pollutants from Agri lands due to diffused use of fertilizers and presence of residual chemicals/ slurry in soil even in controlled catchment management [20]. There is a need of controlling the pollution sources from the fields by controlling application of fertilizers/ manures, over grazing, tillage, cross slope cultivation, edge of fields/ buffer zones, wetlands, maintenance of surface runoff and ditches/ drains in the catchment areas [21,22]. The pollutants can be point source or diffuse pollution in the form of Nutrients/ waste from agriculture/ farmlands, chemicals/ waste from industry/roads/ surface drainage, sewerage treatment plants disposal, waste/ leakages from sewerage systems of rural/ urban 
population, microplastic, pharmaceuticals or modified structures [23]. These pollutants are responsible for bad water quality which largely affect the aqua life in the form of decreased biodiversity, genetic variations of species in water, algae/ bacteria/ coliform growth, dead zones due to decreased dissolved oxygen and sediments concentration. A per OFWAT (2011), England and Wales extract more than 55 billion litres/day from ecological water cycle which is equal to Winder Lake water. Water companies supply 15 billion litres/ day as treated water for domestic use, and they have charged customers $£ 30$ billion for treatment/ disposal of this water To minimize this amount and to reduce the impact on ecosystem by extraction of this much of water, Billions of pounds have been spent on catchment management to get good quality raw water and return it back to environment with less treatment effort [24]. The pollutants are dissolved/ diluted by attenuation in river streams in open channel flow but extraction of huge amount of water affects this attenuation/ dilution capability of water. Therefore, best catchment management practices are required to maintain the water cycle with minimum disturbance. Fresh water is extracted from environment and used for different purposes. During use, water gets polluted by human and after treatment by Wastewater Treatment Plants (WWTP) and then it is released back in water streams. The treated water is not $100 \%$ free from pollutants/ chemicals and badly disturbs the water cycle in quality/ quantity both. As per press release of Environment Agency EA (2019) on efficacy of WWTP in UK, the standards achieved by the water companies in their WWTP since 2011, has deteriorated due to increase in sewage mixing occurrences in 2018. Only Northumbrian Water, one out of 9 water companies in UK, has achieved passing standards [25]. The partially treated water from these treatment plants is a source of pollution like pharmaceutical/ cosmetics residuals/ chemicals [26,27], microfibers/ microplastics [28,29] faecal coliform bacteria and other pathogens [30]. As per WWF (2019), one of the major causes of failing of UK rivers in getting good ecological status is pollution from WWTP as it impacts around $40 \%$ of UK rivers. It is imperative to modernize the WWTP to work as per the standards laid down by EU WFD and those specified by Environment Agency UK, otherwise UK may not be able to meet the 2021 \& 2027 WFD targets [30]. UK customers are paying around $£ 1.25$ Billion annually as their water/ sewerage bills to water companies for the treatment of fresh/ wastewater, since 1989. Therefore, water companies are required to invest more on their plants and catchment management as a good preventative measure to maintain quality of water in rivers [31].

\section{Some catchment management schemes and their efficacy in reducing water pollution throughout river catchment}

The best management practice to maintain a River Catchment is to control pollution entering the rivers from agriculture and farmlands. The bulk source of sediments, nitrate and phosphate to rivers is due to soil erosion/ use of fertilizers/ slurry in agriculture/ grazing fields which cause growth of algae and decrease in dissolved oxygen in water streams. Following paragraphs give details of some catchment schemes and their efficacy in getting desired results:
SCaMP 1,2 and 3 by United Utilities since 2005 to 2020 are the catchment management examples in which around 60,000 hectares of land has been managed with catchment sensitive farming, forestation, peatland drains blockage, re-vegetation and fencing etc. There have been improvements/ steady results in water quality as regards the colour, dissolved oxygen, dissolved organic carbon, less soil erosion/ sediment transport, rehabilitation of natural habitats to some extent with temporal/ spatial variations because of these schemes though lesser than the desired results.

However, more area is required to be managed to get better results in the catchment with participation/ finances of farmers, NGOs and government organization [32]. Collins [33] in their study of implementation of 12 onsite nutrients/ sediment control measures on farmlands in UK found that a localized impact on reduction in the levels of nitrate by $2.5 \%$, phosphate by $11.9 \%$ and Sediments by $5.6 \%$ was observed with annual cost of $£ 52 /$ hectare. It will cost around $£ 450$ million for whole agriculture land in UK annually to decrease the levels by these small levels. The $100 \%$ efficacy of these catchment practices involve more than 700 measures which are required to be fully controlled for the desired results of WFD with enormous investment and willingness participation of farmers [33].

DPIWE (2003), Department for primary industries, water and environment Tasmania carried out study on water quality of Montagu River after decades of its catchment management and found out very less improvement in quality of water as all indicators about nutrients, sediments, coliform bacteria and other physical/ chemical impurities remained more than the specified limits in almost all the reaches of the river thus showing hardly any success of catchment management to improve the water quality. The failure was caused mainly by non-implementation of the required practices, no control on use of fertilizers on farmlands, no proper disposal of sewerage/ industrial waste, lack of public participation and lack of finances [34].

McDowell [35] carried out the study for assessment of water quality in Pomahaka River catchment in New Zealand after decades of management for levels of nitrates, phosphate, suspended solids and $E$-coli bacteria. Very little improvement was observed in the length of the river with a lot of spatial/ temporal variations. Overall, the given indicators could not get better improvements due to application of fertilizers/ slurry on wet soils, unvegetated fields in non-crops season, ploughing of wet soils, direct ingress of animal faecal from Sheep and dairy farms and mixing of overflow sewerage from urban/ rural population [35].

Kay [36] studied Ingbirchworth reservoir catchment area to determine efficacy of catchment management which was declared Nitrate Vulnerable Zone (NVZ) under EA in 2002 and associate catchment ECSFDI in 2006 (England catchment sensitive farming Delivery Initiative ECSFDI). It comprises 3 reservoirs mainly surrounded by grazing lands of livestock with very less arable land. EA has managed the monitoring of this area by taking fortnightly samples at 11 points. They used the long-term data of EA and took 
50 samples to determine the improvements in water quality. A partial success of catchment management in nitrate and phosphate levels in last 3 decades was observed that too only in a few streams having variations of levels lesser/ more than the specified limits in different peak times showing temporal/ spatial variations. The conclusion was drawn that localized management can give a better result for a local area only, however much more is required to be done by public participation and stricter implementation mechanism by government agencies to achieve results in the whole catchment. The results achieved for reduction of nitrates, phosphates and suspended solids over long-term observations of 3 years were found highly susceptible to temporal and spatial variations though partial improvement has been achieved as shown by ranges, median values and lower/ higher limits with first and fourth quartile box graphs as given in Figure 3; [36].

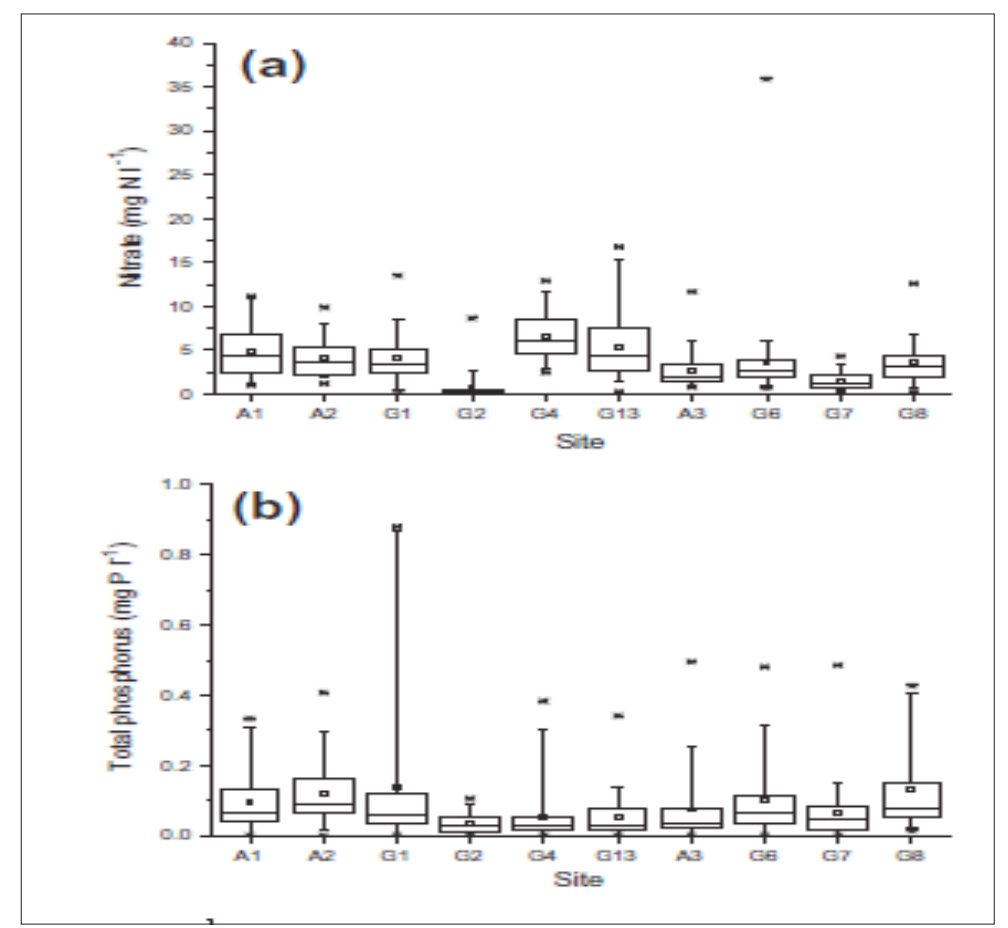

Figure 3: Presence of Nitrate and Phosphate in Ingbirchworth/ Scout Dyke 2006-2009 [36].

There is a need to interact with farmers to implement catchment sensitive practices like how, when and what quantity of fertilizers to be used, how to use slurry like injecting into the soil instead of spraying it on the soil, how to store the slurry, pesticides, insecticides and fertilizers etc away from water channels under the roof. How to do soil tillage and at what time. They should not plough the fields when soil is wet, should not spray in rainy weather, should maintain a buffer zone in between the water channel and crops edge, should grow a cover crop to stop sediments entry from naked soil and they should have mixed breeds/ types of animals as livestock [24,3739]. DEFRA is interacting with farmers by frequent site visits of its employees to give guidelines and to do audit of implementation of DEFRA guidance/ rules. However, there is a direct requirement of public sector financing as the voluntary schemes are not achieving the desired results. There is a requirement of giving subsidies/ financial benefits to farmers as per the target-oriented success rate instead of subsidies on unit rate. DEFRA has entry level and high-level stewardship agricultural schemes for better agriculture practices as per England catchment sensitive farming Delivery Initiative (ECSFDI), but all is required to be linked to successoriented financing/ punitive measures $[39,40]$.

\section{Methodology}

Samples were collected from 9 inlets/ streams sources to Ingbirchworth reservoir (IB 1 to IB9) and 4 samples were taken from inlet streams to Scout Dyke reservoir (S1 to S4). Readings for $\mathrm{PH}$, conductivity, temperature and dissolved oxygen were taken at sites. Water samples were tested in laboratory for Alkalinity, SS, phosphates PO4_P, ammonia NH4_N, nitrates $\mathrm{NO}_{3}+\mathrm{NO}_{2}-\mathrm{N}$ and $\mathrm{NO}_{2}-\mathrm{N}$. Aqua800 advanced qualitative analyser/method was used in laboratory to analyse nutrients. Total phosphorus was converted to active "P" by hydrolyses through mixing of potassium per-sulphate in portion of sample and value was measured. SS was measured by passing $500 \mathrm{ml}$ sample water through $0.45 \mu \mathrm{m}$ filter and measuring the difference in weight of dry filter before and after passing the solution to measure the retained solids particles on dried up filter in the oven. Field observations were taken having a complete round of the area, fields, farms and reservoir inlet streams physically to check the on-ground condition of grasslands, animal farms, use of slurry, silage, loose soil after ploughing, extent of buffer zones and maintenance of cover and slope by farmers. The biggest farm in the catchment areas of Ingbirchworth was visited to meet the managers and farmers to know their farming techniques/ quantities used 
for fertilizers/ slurry applications, maintenance of buffers along water channels, soil cover, methods of ploughing, drainage, storage of chemicals, use of machines, their understanding of government schemes and desire to participate voluntarily in stewardship schemes in NVZs.

\section{Result}

Results of tests conducted at site and laboratory are appended in Table 1 for Scout Dyke reservoir and in Table 2 for Ingbirchworth reservoir. Water Quality standards are appended in Table 3.

Table 1: Water samples test results-scout dyke compensatory reservoir.

\begin{tabular}{|c|c|c|c|c|c|c|c|c|c|c|}
\hline Lab ID & $\mathrm{NH}_{4^{-}} \mathrm{N}$ & $\mathrm{NO}_{2} \mathrm{~N}$ & $\left(\mathrm{NO}_{3} \mathrm{~N}\right)$ & $\mathrm{PO}_{4^{-}} \mathrm{P}$ & Temp & pH & DO & Conductivity & SS & Alkalinity \\
\hline & $\mathrm{mg} / \mathrm{L}$ & $\mathrm{mg} / \mathrm{L}$ & $\mathrm{mg} / \mathrm{L}$ & $\mathrm{mg} / \mathrm{L}$ & $\mathbf{C}^{\circ}$ & & $\mathrm{mg} / \mathrm{L}$ & $(\mu \mathrm{S} / \mathrm{cm})$ & $\mathrm{mg} / \mathrm{L}$ & \\
\hline S1 & 0.01767 & 0.021 & 3.426 & 0.003 & 7.4 & 7.21 & 11.23 & 247 & 31.29 & 319.58 \\
\hline S2 & 0.01209 & 0.006 & 4.422 & 0.008 & 7 & 6.95 & 11.09 & 209.1 & 4.03 & 173.077 \\
\hline S3 & 0.01488 & 0 & 10.818 & 0.012 & 7.3 & 6.86 & 10.9 & 320 & 14.75 & 120.482 \\
\hline S4 & 0.0093 & 0.004 & 6.3451 & 0.044 & 7.1 & 7.41 & 11.39 & 342 & 4 & 198.473 \\
\hline
\end{tabular}

Table 2: Water samples test results-ingbirchworth drinking water reservoir.

\begin{tabular}{|c|c|c|c|c|c|c|c|c|c|c|}
\hline Lab ID & $\mathrm{NH}_{4-} \mathrm{N}$ & $\mathrm{NO}_{2-} \mathrm{N}$ & $\left(\mathrm{NO}_{3} \mathrm{~N}\right)$ & $\mathrm{PO}_{4-} \mathrm{P}$ & Temp & pH & DO & Conductivity & SS & Alkalinity \\
\hline & $\mathrm{mg} / \mathrm{L}$ & $\mathrm{mg} / \mathrm{L}$ & $\mathrm{mg} / \mathrm{L}$ & $\mathrm{mg} / \mathrm{L}$ & $\mathbf{C}^{\circ}$ & & $\mathrm{mg} / \mathrm{L}$ & $(\mu \mathrm{S} / \mathrm{cm})$ & $\mathrm{mg} / \mathrm{L}$ & \\
\hline IB1 & 0.1767 & 0 & 4.797 & 0.013 & 7.3 & 6.88 & 10.56 & 326 & 0.8 & 288.462 \\
\hline IB2 & 0.1729 & 0 & 4.77 & 0.013 & 7.2 & 7.07 & 5.32 & 377 & 1.33 & 873.239 \\
\hline IB3 & 0.0046 & 0 & 9.612 & 0.006 & 7.2 & 5.5 & 9.56 & 216 & 0 & 49.7238 \\
\hline IB4 & 0.00558 & 0 & 10.269 & 0.009 & 7.3 & 5.56 & 10 & 294 & 0 & 44.8718 \\
\hline IB5 & 0.00744 & 0.003 & 9.528 & 0.005 & 7.1 & 6.54 & 11.25 & 302 & 0.67 & 111.765 \\
\hline IB6 & 0.01302 & 0.005 & 1.336 & 0.006 & 7.2 & 6.36 & 11.64 & 84.1 & 5.69 & 24.3902 \\
\hline 1B7 & 0.01395 & 0.004 & 6.224 & 0.007 & 7 & 6.77 & 11.63 & 193.4 & 1.13 & 59.6026 \\
\hline IB8 & 0.00372 & 0 & 6.777 & 0.006 & 7.3 & 6.8 & 11.63 & 269 & 2.56 & 57.3248 \\
\hline IB9 & 0.01953 & 0 & 4.743 & 0.006 & 7.1 & 6.35 & 10.39 & 149.2 & 122.67 & 64.1026 \\
\hline
\end{tabular}

Table 3: Water quality standards for chemicals and water characteristics [41-47].

\begin{tabular}{|c|c|}
\hline Chemicals/ Characteristic & Standards \\
\hline $\mathrm{NH}_{4-} \mathrm{N}$ & $<0.15 \mathrm{mg} / \mathrm{L}$ \\
\hline $\mathrm{NO}_{{ }_{-}} \mathrm{N}$ & $<0.1 \mathrm{mg} / \mathrm{L}$ \\
\hline $\mathrm{NO}_{3-} \mathrm{N}$ & $<11.3 \mathrm{mg} / \mathrm{L}$ \\
\hline $\mathrm{PO}_{4-} \mathrm{P}$ & $<0.1 \mathrm{mg} / \mathrm{L}$ \\
\hline $\mathrm{pH}$ & $5.5-9$ \\
\hline $\mathrm{DO}$ & $8-15 \mathrm{mg} / \mathrm{L}$ \\
\hline Conductivity & $200-800 \mu \mathrm{S} / \mathrm{cm}$ \\
\hline Suspended Solids (SS) & $<25 \mathrm{mg} / \mathrm{L}$ \\
\hline Alkalinity & $20-500 \mathrm{mg} / \mathrm{L}$ \\
\hline
\end{tabular}

\section{Discussion/ Analysis}

The results show that the all the chemicals/ characteristics of water streams feeding both Ingbirchworth and Scout dyke reservoirs are well within the range which interpret a well-managed catchment sensitive farming in adjacent areas from where water is flowing into these reservoirs. However, results highlighted with red are on higher side and need to be controlled, orange colour results are moderately high and yellow colour results are slightly on higher side, whereas green colour results are in desirable limits. Following can be inferred on comparison/ analysis of results with standard freshwater limits for each chemical/ characteristic:

\section{Ammonia}

Ammonia is found in water due to fertilizers used for crops, microbiological decay of animal and plant waste and domestic pollution from urban areas and farms. Its range is up-to $0.15 \mathrm{mg} / \mathrm{L}$ $[41,42]$. All the samples results are well within the range except first sampling site in Ingbirchworth "IB1" where there was a dump of decaying grass/ plant and second site "IB2" which is source of underground water which is generally rich in ammonia due to microbiological decay activity going underground.

\section{Nitrite nitrogen}

It is active but decomposable form of nitrogen which oxidise quickly to nitrate. Its range is maximum up to $0.1 \mathrm{mg} / \mathrm{L}$ in water $[41,42]$. All the samples were found with nitrites much lesser than this range with no significant impact on water quality.

\section{Nitrate nitrogen}

It is the most stable form of nitrogen and influential part of nutrients present in the water. Its source is mainly the fertilizers used on the crops in catchment area. Nitrates come from surface drainage of arable land, decomposition of waste by aerobic 
bacterial activity and lightening converts atmospheric oxygen into nitrates. High concentration of nitrates in water shows increased use of fertilizers having nitrates compounds and use of slurry/ manure as fertilizers on arable fields. Its limit is $11.3 \mathrm{mg} / \mathrm{L}$ or $50 \mathrm{mg}$ $\mathrm{N} / \mathrm{L}[41,42]$. All the samples were generally found within the limits, however, Samples from third sampling site in Scout Dyke "S3" and sites IB3, IB 4 and IB 5 in Ingbirchworth have exhibited maximum presence of nitrates to the tune of 9 to $10 \mathrm{mg} / \mathrm{L}$ suggesting the runoff from heavily fertilized fields.

\section{Phosphate}

Phosphates are found in water as inorganic phosphorous "P" or organic phosphates " $\mathrm{PO}_{4}$ " more commonly in fertilizers, detergents, wastewater, effluents, underground minerals $[41,42]$. Muller and Helsel (1996) have explained phosphate as a nutrient required for aquatic plant and Algal growth. Its concentration more than $0.020 \mathrm{mg} / \mathrm{L}$ is considered Eutrophic (rich nutrients, less D0, more plant growth and dangerous for aqua life), from 0.01 to 0.02 is mesotrophic and less than 0.01 is oligotrophic [43-46]. As per results, the site S4 in Scout Dyke falls in Eutrophic region and dangerous for Algal growth i.e., Blue Green Algae Blooms. Site S3 and IB1 \& IB2 in Ingbirchworth drinking reservoir fall in Mesotrophic region and have medium risk of Blue green Algal blooms. Presence of Phosphates is linked with presence of more SS in water for its long duration persistence in water with less decomposition [4749].

\section{Temperature}

Temperature of all water samples was found to be 7 to 7.4 centigrade which was a moderate temperature in winter months in UK at the time of sampling.

\section{pH}

It is the measure of count of $\mathrm{H}^{+}$ions in water. $\mathrm{pH} 7$ is neutral and desirable, however $\mathrm{pH}$ range of 6.5 to 9 is considered normal [45]. All the samples taken from the sites show good pH of 6.3 to 7.4 except samples from sites IB3 and IB4 which show moderately acidic $\mathrm{pH}$ values of around 5.5 .

\section{Dissolved Oxygen DO}

The DO test is an important aspect of water quality and presence of aqua life. The minimum limit of DO is 8 to $15 \mathrm{mg} / \mathrm{L}$ [45]. All samples results are showing good quantity of DO from 9.5 to $11.6 \mathrm{mg} / \mathrm{L}$ except sample from IB2 having DO of $5.32 \mathrm{mg} / \mathrm{L}$ near to dead level which is the source of underground water to Ingbirchworth reservoir. All samples result of Scout Dyke reservoir are good and show good treatment of wastewater by recently installed treatment plant before leaving the water into compensatory reservoir.

\section{Conductivity}

The conductivity of water shows its ability of passing through the electric current through number of ions present in water due to dissolved salts and inorganic materials. Standard range of conductivity is $200-800 \mu \mathrm{S} / \mathrm{cm}[45,46]$. All the samples have conductivity well within the range.

\section{Suspended Solids SS}

Anything that retains on $0.45 \mu \mathrm{m}$ is called a suspended solid and passing through it as dissolved solids [46]. SS come from surface run off, soil, waste and wastewater and their recommended range is up to $25 \mathrm{mg} / \mathrm{L}$. All the samples have good range of SS except sites S1 in Scout Dyke and IB9 in Ingbirchworth reservoirs possibly due to over greasing on adjacent lands, less vegetable cover and fresh tillage before a surface run off event.

\section{Alkalinity}

It is the ability of water to neutralize acidity by the presence of bicarbonate, carbonate, and hydroxide ions. The minimum limit of Alkalinity is 20 to $500 \mathrm{CaC} 03 \mathrm{mg} / \mathrm{l}$. Whereas all samples results are varying from 24 to 320 except sample from IB2 having Alkalinity of 873 which is the source of underground water to Ingbirchworth reservoir.

\section{Possible Catchment Management Strategies}

It is evident from the results/ analysis that presence of all kind of pollutants in a reservoir depends mainly on catchment areas. Therefore, catchment management with sensible farming techniques and proper control on Nitrate vulnerable zones in the vicinity of a reservoir is an essential requirement. DEFRA in UK has got a lead regulatory role in maintaining the Catchment sensitive farming. Although "Environmental Agency (EA)" and "Natural England" along with other NGOs and farmers are undertaking concerted efforts to implement policy guidelines from "England Catchment Sensitive Farming Delivery Initiative (ECSFDI), "Diffuse Water Pollution from Agriculture (DWPA)" to meet the EU WFD [13]. Following are the suggested strategies to reduce water pollution from agriculture and farmlands:

1. Result oriented implementation of ECSFDI is essential for regulation of all catchments throughout UK by properly employing advisory groups through increased interaction/ awareness to farmers [37].

2. Ample regulations (172 regulations/ act of parliament), advisory groups and bodies (DEFRA) have been formed but these should be implemented in simplified manner to the level of farmer's understanding by removing all complexities and long procedures [13].

3. Maximizing opportunities and minimizing risks policy with stick and carrot methodology can be a good strategy to gain results from DEFRA regulations in Catchment Sensitive Farming (CSF) and nitrate-controlled agriculture zones.

4. Mutually beneficial outcome-based strategies should be preferred on forced managed based policies to increase the voluntary contribution by farmers/ stake holders.

5. Supportive/ collaborative approach of regulators with less punitive measures instead of forced implementation is likely to generate better results among the farmers.

6. Maintaining a buffer zones (non-cultivated strips) of 1 to $6 \mathrm{~m}$ 
along water streams to separate the cultivated land is highly recommended as it can serve as an absorption filter to prevent direct entry of pollutants into the water.

7. Improvement of land cover/ loose soil protection should be ensured by proper compaction, post-harvest field erosion, farming in waterlogged land, maintenance of good slope and prevention of over grazing. This can ensure less transportation of suspended solids into the water.

8. Keeping the fertilizers, slurry and manure under roof and use of injection methods instead of spray method of fertilizer's application to avoid spillage. Low level spray machines to spray only approved fertilizers/chemicals preferably organic materials on crops only.

9. Mix animals farms to be preferred to avoid damage to land. Pigs farm result into more damage to farmlands than sheep farming.

10. Treatment of animal/ human wastage, sewage and urban wastage before they get mixed with water should be ensured.

11. Transformation of arable land to low impact animal farmland is a better strategy (if feasible basing on national demand/ production) to reduce impact of agriculture/ fertilizers on a reservoir.

12. Implementation of reforms of common agriculture policy 2005 by complying to Cross Compliance subsidies basing on production, Entry level schemes and higher-level scheme of farmers participation [37].

Advantage/Disadvantage of Implementation of Catchment Sensitive Farming

\section{Advantages}

1. Reduced water pollution to water reservoir resulting in lesser risks of epidemics and diseases.

2. Reduced cost on purification of drinking water by water companies.

3. Land protection from damages.

4. Improved land cover.

5. Increased financial benefits to well-regulated farmers.

\section{Disadvantages}

1. Decreased output of farms.

2. Loss to farmers profit.

3. Complexities in farming business in implementation of different techniques.

4. Punitive measures on farmers on non-compliance.

5. Dissatisfied farmers due to less profit, reduced production and restrictions on free farming practices.
6. Employment of enhanced inspection staff for increased field visits/ inspections by DEFRA will cause more expenditure to exchequer and will increase unrest in farmers.

\section{Conclusion}

Ingbirchworth catchment area is one of the associate catchments projects for CSF started since September 2006. A considerable control on pollution by nutrients and SS have been recorded since inception of the programme but presence of pollutants/ nutrients on higher limits at certain places is still alarming. The implementation of steward scheme and catchment sensitive farming in Ingbirchworth reservoir catchment areas have attained partial success since 2006 as studied by Kay [36] from 2006-2009. The results in this study also show significant betterment in almost all fields though at places, results on the higher limit side have been detected especially Nitrate $\mathrm{N}$ nearing to $11.3 \mathrm{mg} / \mathrm{L}$ limit showing use of fertilizers, dissolved oxygen lowering less than $8 \mathrm{mg} / \mathrm{L}$ showing Eutrophication process resulting into low oxygen level dangerous for aqua life. Similarly, suspended solids have also been noticed at some places exceeding the top limit of $25 \mathrm{mg} / \mathrm{L}$ showing drained water carrying soil particles from uncovered land surface. However, a lot is required to be done to control the use of fertilizers as per the desired standards and methodology of application. It can be inferred from beautiful green grazing fields and arable land in the catchment areas in UK that excessive use of fertilizers, slurry and other farming techniques are still in place with full swing. Because of these mal practices, of more than 4600 water bodies and 3700 rivers in UK, only 16\% have achieved good status and $63 \%$ have got moderate results of achieving water quality standards [50,51]. There is a need to implement the regulations in fullest capacity by employing production-based result oriented, collaborative technical/ financial support to those farmers who voluntarily implement CSF programme while using stringent measures against the defaulters in UK as this is pre-requisite for preservation of clean water for present/future generations/ species. There have been numerous catchment management plans under EA and all the water companies in UK, but all these schemes have achieved partial success. The main framework of any catchment management strategy should encompass good planning, wilful participation, strenuous execution, long term sustainability, wholistic consideration of all factors in all sub catchments, rigorous monitoring and reporting with rewards/ punitive measure. To achieve gross efficiency/ success of these schemes, it would be imperative to have voluntary public participation, target oriented incentives/ funding by all stakeholders, preservation of natural habitat/ river courses and carrying out more recorded studies with scientific interventions/ farm advisories to detect/ control all kind of pollutants entering the water streams.

\section{Acknowledgement}

This research was carried out with the help of teaching/ laboratory staff and students at University of Leeds and staff in Ingbirchworth farm/ reservoir and Scout Dyke reservoir. 


\section{References}

1. European Commission (2000) Directive 2000/60/EC water framework directive 22 December 2000.

2. (2020) European Union Water Framework Directive (2000/60/EC amended 2012).

3. EA (2019) Water and sewerage companies in England: Environmental performance report 2018, UK.

4. NAO (2010) Tracking diffuse water pollution from agriculture DWPA in England, controller/ auditor general.

5. OECD (2012) Better policies to improve the environmental performance of the agriculture sector.

6. Meng H, Matthan NR, Ausman LM, Lichtenstein AH (2017) Effect of macronutrients and fiber on postprandial glycemic responses and meal glycemic index and glycemic load value determinations. Am J Clin Nutr 105(4): 842-853

7. Kallis G, Butler D (2001) The EU water framework directive: Measures and implications. Water Policy 3(2): 125-142.

8. Kaika M (2003) The water framework directive: A new directive for a changing social, political and economic European framework. European Planning Studies 11(3): 299-316.

9. Adshead J (2004) River basin management in the water framework directive: An integrated approach to water protection and management. Water Law 15: 5-11.

10. Grimeaud D (2004) The EC water framework directive-an instrument for integrated water policy. Review of European Community \& International Environmental Law 13(1): 27-39.

11. (2018) EU Water Conference 20-21, Viana Austria.

12. Collins AL, Newell PJP, Zhanga Y, Gooday R, Nadend PS, et al. (2018) Assessing the potential impacts of a revised set of on-farm nutrient and sediment 'basic' control measures for reducing agricultural diffuse pollution across England. Science of the Total Environment 621: 14991511.

13. DEFRA (2018) Farm inspection and regulation review: Summary and recommendations.

14. Jonge D, Elliott VN, Orive ME (2002) Causes, historical development, effects and future challenges of a common environmental problem: Eutrophication. Hydrobiology 475/476: 1-19.

15. Syvitski JPM, Vorosmarty CJ, Kettner AJ, Green P (2005) Impact of humans on the flux of terrestrial sediment to the global coastal ocean. Science 308(5720): 376-380.

16. Edwards AC, Withers PJA (2008) Transport and delivery of suspended solids, nitrogen and phosphorus from various sources to freshwaters in the UK. Journal of Hydrology 350(3-4): 144-153.

17. Hunt DTE, Dee AS, Oakes DB (2004) Updating an estimate of the sources of nitrogen to UK waters-Phase 2. Defra Final Report for Project WT03016.

18. DEFRA (2007) The protection of waters against pollution from agriculture: Consultation on diffuse sources in England.

19. DEFRA (2009) Protecting our water, soil and air-a code of good agricultural practice for farmers, growers and land managers.

20. Ockenden MC, ClareD, John NQ, Alison PB, Ben S, et al. (2012) Evaluation of field wetlands for mitigation of diffuse pollution from agriculture: Sediment retention, cost and effectiveness. Environmental Science and Policy 24: 110-119.

21. Braskerud BC, Tonderski KS, Wedding B, Bakke R, Blankenberg AGB, et al. (2005) Can constructed wetlands reduce the diffuse phosphorus loads to eutrophic water in cold temperate regions? Journal of Environmental Quality 34(6): 2145-2150.

22. Vymazal J (2011) Enhancing ecosystem services on the landscape with created, constructed and restored wetlands. Ecological Engineering 37(1): 1-98

23. Meng C, Wang Yi, Yuyan Li, Jiaogen Z, Yong Li, et al. (2017) Deteriorated water quality of agricultural catchments in South China by net anthropogenic phosphorus inputs. Sustainability 9(9): 1480.

24. Howarth W (2011) Diffuse water pollution and diffuse environmental laws. Journal of Environmental Law 23 (1): 129-141.

25. OFWAT (2011) Can upstream catchment management deliver a better deal for water customer and environment, Office of Water Services UK (OFWAT) Water today water tomorrow-catchment to customer.

26. EA (2019) Water and sewerage companies in England: Environmental performance report 2018.

27. Kay P, Hughes S, James R, Alison E, Lee E (2017) Widespread, routine occurrence of pharmaceuticals in sewage effluent, combined sewer overflows and receiving waters. Env Pollution 220: 1447-1455.

28. Carter L, (2019) Emerging containments in Urban Rivers, lecture in module geography 5570, England.

29. Cormick MA, Hoellein TJ, Mason SA, Schluep J, Kelly JJ (2014) Microplastic is an abundant and distinct microbial habitat in an urban river. Environ Sci Technol 48(20): 11863-11871.

30. Kay P, Hiscoe R, Moberley I, Bajic L, Kenna MN (2018) Wastewater treatment plants as a source of microplastics in river catchments. 25: 20264-20267.

31. WWF (2019) Healthy rivers critical to global efforts to adapt to climate change. Europe.

32. OFWAT (2011) Review of Ofwat and consumer representation in the water sector. UK.

33. United Utilities (2019) Sustainable Catchment Management Plan, SCaMP1-3.

34. Collins AL (2018) Assessing the potential impacts of a revised set of on-farm nutrient and sediment 'basic' control measures for reducing agricultural diffuse pollution across England. Science of the Total Environment 621: 1499-1511.

35. DPIWE (2003) State of the river report for the montagu river catchment. Water assessment and planning branch, Department of primary industries, Water and environment, Hobart, Australia, pp. 1449-5996

36. Dowell RW, Monaghan R, Muirhead RW, Cox N (2011) Water quality of pomahaka river catchment: Scope for improvement. New Zeeland.

37. Kay P, Grayson R, Phillips M, Stanley K, Dodsworth A, et al. (2012) The effectiveness of agricultural stewardship for improving water quality at the catchment scale: Experiences from an NVZ and ECSFDI watershed. Journal of Hydrology 422-442: 10-16.

38. Kay P, Edwards AC, Foulger M, (2009) A review of the efficacy of contemporary agricultural stewardship measures for addressing water pollution problems of key concern to the UK water industry. Agric Syst 99(2-3): 67-75.

39. DEFRA (2016) The guide to cross compliance in England.

40. DEFRA (2018) Farm inspection and regulation review: Summary and recommendations.

41. Edwards AC, Withers PJA (2007) Linking phosphorus sources to impacts in different types of water body. Soil Use Manage 23 (S1): 133-143.

42. (2003) HACH Water Analysis Handbook, Hach Company. 
43. Joseph AC (2017) WHO guidelines for drinking water quality: First addendum to the fourth edition. Journal AWWA 109(7): 44-51.

44. Mueller DK, Helsel DR (1996) Nutrients in the nation's waters-too much of a good thing? p. 24.

45. WHO (2005) Guidelines for drinking-water quality first addendum to third edition: $1: 668$.

46. DWI (2014) Drinking Water Inspection UK by Chief Inspector DWI DEFRA UK

47. APHAJ998 (1998) EPE surface water quality parameters for inspection.
48. (2018) Yorkshire water annual report.

49. Philip J, John P (2017) Updating the estimate of the sources of phosphorus in UK waters. UK.

50. Jarvie HP, Neal C, Withers PJA, Robinson A, Salter N (2003) Nutrient water quality of the wye catchment, UK: Exploring patterns and fluxes using the Environment Agency data archives. Hydrology and Earth Systems Sciences 7: 722-743.

51. Klaar MJ (2018) Introduction to river basin management, policy and legislation. Geography 5570.

For possible submissions Click below: 